Article

\title{
An Effective D- $\pi$-A Type Donor Material Based on 4-Fluorobenzoylacetonitrile Core Unit for Bulk Heterojunction Organic Solar Cells
}

\author{
Shabaz Alam ${ }^{1}\left(\mathbb{D}\right.$, M. Shaheer Akhtar $^{2} \mathbb{D}$, Abdullah ${ }^{1,3}\left(\mathbb{D}\right.$, Eun-Bi Kim ${ }^{1}$, Hyung-Shik Shin ${ }^{1,4, *(\mathbb{D})}$ \\ and Sadia Ameen ${ }^{3, *}$ \\ 1 Energy Materials \& Surface Science Laboratory, Solar Energy Research Center, \\ School of Chemical Engineering, Jeonbuk National University, Jeonju 54896, Korea; shabaz@jbnu.ac.kr (S.A.); \\ abdullahazmi@jbnu.ac.kr (A.); xxot3699@jbnu.ac.kr (E.-B.K.) \\ 2 New \& Renewable Energy Material Development Center (NewREC), Jeonbuk National University, \\ Buan-gun 56332, Korea; shaheerakhtar@jbnu.ac.kr \\ 3 Advanced Materials \& Devices Laboratory, Department of Bio-Convergence Science, Jeongeup Campus, \\ Jeonbuk National University, Jeongeup 56212, Korea \\ 4 Korea Basic Science Institute (KBSI), 169-148 Gwahak-ro, Yuseong-gu, Daejon 34133, Korea \\ * Correspondence: hsshin@jbnu.ac.kr (H.-S.S.); sadiaameen@jbnu.ac.kr (S.A.); Tel.: +82-63-270-2438 (S.A.); \\ Fax: +82-63-270-2306 (S.A.)
}

check for updates

Citation: Alam, S.; Akhtar, M.S.; Abdullah; Kim, E.-B.; Shin, H.-S.; Ameen, S. An Effective D- $\pi$-A Type

Donor Material Based on

4-Fluorobenzoylacetonitrile Core Unit for Bulk Heterojunction Organic Solar Cells. Appl. Sci. 2021, 11, 646. https://doi.org/10.3390/ app11020646

Received: 25 November 2020 Accepted: 29 December 2020 Published: 11 January 2021

Publisher's Note: MDPI stays neutral with regard to jurisdictional clai$\mathrm{ms}$ in published maps and institutional affiliations.

Copyright: $(\odot 2021$ by the authors. Licensee MDPI, Basel, Switzerland. This article is an open access article distributed under the terms and conditions of the Creative Commons Attribution (CC BY) license (https:// creativecommons.org/licenses/by/ $4.0 /)$.

\begin{abstract}
In order to develop new and effective donor materials, a planar donor- $\pi$-acceptor (D- $\pi$-A) type small organic molecule (SOM), 2-(4-fluorobenzoyl)-3-(5"-hexyl-[2,2':5',2"-terthiophen]-5-yl) acrylonitrile, named as H3T-4-FOP, was synthesized by the reaction of 4-fluorobenzoylacetonitrile (as acceptor unit) and hexyl terthiophene (as donor unit) derivatives. Promising optical, solubility, electronic and photovoltaic properties were observed for the H3T-4-FOP SOM. Significantly, the presence of 4-fluorobenzoylacetonitrile as an acceptor unit in H3T-4-FOP SOM tuned the optical band gap to $\sim 2.01 \mathrm{eV}$ and procured the reasonable energy levels as highest occupied molecular orbital (HOMO) of $-5.27 \mathrm{eV}$ and lowest unoccupied molecular orbital (LUMO) $-3.26 \mathrm{eV}$. The synthesized H3T-4-FOP SOM was applied as a donor material to fabricate solution-processed bulk heterojunction organic solar cells (BHJ-OSCs) with an active layer of H3T-4-FOP: PC $_{61} \mathrm{BM}(1: 2, w / w)$ and was validated as having a good power conversion efficiency (PCE) of $\sim 4.38 \%$. Our studies clearly inspire for future designing of multifunctional groups containing the 4-fluorobenzoylacetonitrile based SOM for high performance BHJ-OSCs.
\end{abstract}

Keywords: 4-fluorobenzoylacrylonitrile; donor; energy conversion; energy level; organic solar cells

\section{Introduction}

The solar energy resource is considered as one of the most useful renewable energy resources to replace fossil fuels and to reimburse a high global energy demand [1-7]. For more than two decades, extensive research efforts have been focused on bulk-heterojunction organic solar cells (BHJ-OSCs), owing to their distinct features such as ease of processability, small production cost, light weight, mechanical flexibility, and solution-processable manufacturing capability [8-12]. Progressive research has shown the remarkably high power conversion efficiency (PCE) of $>18 \%$ for BHJ-OSCs [13-16]. BHJ-OSCs fabricated with small organic molecules (SOMs) are more attractive due to their well-defined molecular weight, less batch-to-batch variation, higher purity, easy purification, and reproducible synthesis over its polymer counterparts $[17,18]$. Organic semiconductors with high exciton binding energy, short life times in the range of $\sim 10-100 \mathrm{ps}$, and exciton diffusion length of 5-10 $\mathrm{nm}$ range are typically used as the photoactive layer, forming a bulk heterojunction of donor and acceptor materials by ensuring the efficient exciton to dissociate at the D/A interface due to the difference between their frontier molecular orbitals $[19,20]$. The electron 
mobility in OSCs largely depends on the film morphology and molecular architectures. Fullerene derivatives such as [6,6]-phenyl- $\mathrm{C}_{61}$ butyric acid methyl ester (PCBM) are n-type semiconductors with rationally high electron concentrations of $10^{17}-10^{18} \mathrm{~cm}^{-3}$ and are frequently applied to fabricate $\mathrm{BHJ}$-OSCs by virtue of their excellent electron accepting and transporting capabilities [21,22]. Moreover, PCBMs have long-life time polarons, originating from the coherent electron transfer between fullerene molecules and hence, reduce the energy barriers for electron transfer [23].

In organic photovoltaics (OPVs), the most general method for enhancing the photocurrent density (Jsc) and the power conversion efficiency of an organic solar cell is to design and synthesize low band gap materials which match well with the solar spectrum without sacrificing open circuit voltage (Voc). It is suggested that halogenation of an electron accepting unit can enhance the intramolecular charge transfer (ICT) effects and, hence, can exhibit an appreciable reduction in the band gap which is one of the most effective molecular designing strategies for investigating new and effective small organic and polymer semiconductor materials [24-27]. In particular, the fluorine atom, due to its small size, high electronegativity with comparatively small Van der Walls radius is proficient at altering the HOMO and LUMO energy levels, extending the absorption, and increasing the electron mobility without undesirable steric hindrances [28]. Moreover, fluorine substitution also induces a rigid and planar backbone in the molecules due to intramolecular hydrogen bonds [29]. To achieve high performance BHJ-OSCs, the active organic layer must have materials with a broad absorption spectrum, high molar absorption coefficient, an appropriate alignment of energy levels between D/A layers, large charge mobility and thin film network with nanoscale phase separation [30]. The suitable phase separation difference between $\mathrm{D} / \mathrm{A}$ interface surfaces through an internal driving force can effectively decrease Voc losses by suppressing recombination [31,32]. Thiophene-based molecular semiconductors are commonly used materials for organic photovoltaics owing to their remarkable thermal, optical and electronic properties. The thiophene ring provides a prominent contribution to its derivatives towards enhanced charge transport and electron donating properties [33]. Recently, Ameen et al. reported a D-A shaped chromophore based on hexyl bithiophene donor and isatin unit as an electron acceptor in the BHJ-OSC device and obtained a PCE of $\sim 4.10 \%$ [34]. In another report, Abdullah et al. synthesized a new hexyl bithiophene containing an efficient asymmetric D-A-A-type small donor molecule, fabricated with a $\mathrm{PC}_{60} \mathrm{BM}$ acceptor for $\mathrm{BHJ}-\mathrm{OSC}$ and achieved promising results with Voc values of $\sim 0.71 \mathrm{~V}$, a Jsc of $\sim 12.56 \mathrm{~mA} / \mathrm{cm}^{2}$, a fill factor (FF) of $\sim 0.42$ with a resulting PCE of $\sim 3.75 \%$ [35].

In this report, we have designed a new asymmetric planar D- $\pi$-A type small organic molecule, 2-(4-fluorobenzoyl)-3-(5"'-hexyl-[2,2':5',2"-terthiophen]-5-yl) acrylonitrile, named as H3T-4-FOP. Herein, the presence of fluorine atom in H3T-4-FOP plays a significant role in molecular energy level alignment and enhancement of the ICT effect due to its high electronegativity and intramolecular hydrogen bonding. The attachment of parallel alkyl side-chain on the thiophene molecular backbone ensures good solution-processibility, molecular packing and improved charge transport properties. In our work, the H3T-4-FOP: $\mathrm{PC}_{61} \mathrm{BM}(1: 2, w / w)$ active layer achieved a reasonable PCE of $\sim 4.38 \%$, Voc of $\sim 0.782 \mathrm{~V}$, Jsc of $\sim 11.18 \mathrm{~mA} / \mathrm{cm}^{2}$ and fill factor (FF) of $50 \%$ under an illumination of $\mathrm{AM} 1.5 \mathrm{G}, 100 \mathrm{~mW} / \mathrm{cm}^{2}$.

\section{Materials and Methods}

\subsection{Materials and Equipment}

All chemicals and reagents including 4-fluorobenzylalcohol, 5-bromo-2-thiophenecarbo xaldehyde, copper chloride, $5^{\prime}$-hexyl-2,2'-bithiophene-5-boronic acid pinacol ester, tetrakis (triphenylphosphine) palladium (0) were purchased from Sigma-Aldrich and used without any further purifications. 


\subsection{Synthesis of H3T-FOP}

2-(4-fluorobenzoyl)-3-(5'-hexyl-[2,2':5' ,2'-terthiophen]-5-yl) acrylonitrile, H3T-4-FOP $\mathrm{SOM}$, was synthesized in three steps, as illustrated in Scheme 1 . The intermediates, 4-fluorobenzoylacetonitrile (1) and 3-5(-bromothiophen-2-yl)-2-(4-fluorobenzoyl) acrylonitrile (2) were prepared as per the reported literature [36,37]. All the intermediates and H3T-4-FOP SOM were analyzed by ${ }^{1} \mathrm{H} N M R,{ }^{13} \mathrm{C}$ NMR and mass spectrometry. The original data are presented in the supporting information (SI).

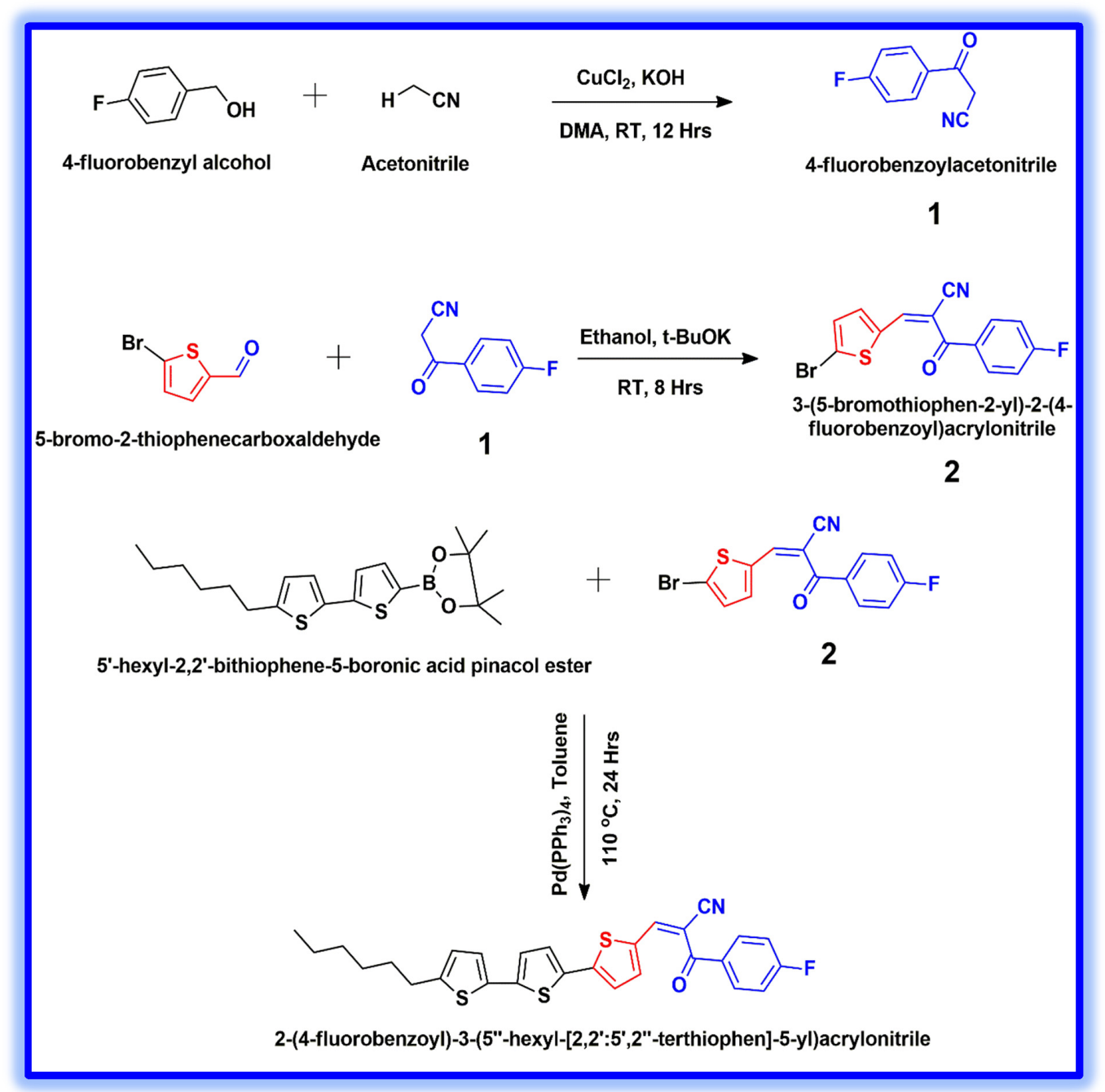

Scheme 1. The synthetic route for 2-(4-fluorobenzoyl)-3-(5"'-hexyl-[2,2':5',2"-terthiophen]-5-yl) acrylonitrile (H3T-4-FOP) small organic molecule (SOM).

\subsection{Synthesis of 4-Fluorobenzoylacetonitrile (1)}

Oxidative cross-coupling reaction was used for the preparation of intermediates (1). 4-fluorobenzylalcohol (4.38 g, $34.73 \mathrm{mmol})$, acetonitrile (18.12 mL, $347.3 \mathrm{mmol}, 10$ equiv.), potassium hydroxide $\left(\mathrm{KOH}, 3.896 \mathrm{~g}, 69.46 \mathrm{mmol}, 2\right.$ equiv.) and copper chloride $\left(\mathrm{CuCl}_{2}\right.$, $2 \mathrm{~mol} \%$ ) were dissolved in dimethylacetamide (DMA, $50 \mathrm{~mL}$ ) and mixed under stirring at room temperature for $12 \mathrm{~h}$ with molecular oxygen as an oxidant [34]. The mixture was filtered and washed with water followed by methanol. A column chromatography was used to purify the desired product (1), using dichloromethane and hexane (DCM: hexane, $1: 3 v / v)$ as eluents. The product was dried in a vacuum oven and the resulted solid was further purified by performing the recrystallization in (DCM: diethyl ether, 1:5 v/v) to obtain the expected product as a white solid (yield 55.19\%, $3.13 \mathrm{~g}) .{ }^{1} \mathrm{H}$ NMR $(500 \mathrm{MHz}$, 
$\left.\mathrm{CDCl}_{3}, \mathrm{ppm}\right) \delta: 7.95(\mathrm{dd}, \mathrm{J}=9.0 \mathrm{~Hz}, 5.2 \mathrm{~Hz}, 2 \mathrm{H}), 7.82(\mathrm{t}, \mathrm{J}=8.2 \mathrm{~Hz}, 2 \mathrm{H}), 4.07(\mathrm{~s}, 2 \mathrm{H}) .13 \mathrm{C}$ $\mathrm{NMR}\left(100 \mathrm{MHz}, \mathrm{CDCl}_{3}\right.$, ppm) $\delta: 185.76,167.73,165.68,131.44,131.36,116.66,116.48,113.75$, 29.47 MS: $\mathrm{m} / \mathrm{z}$ calc. for $\left[\mathrm{C}_{9} \mathrm{H}_{6} \mathrm{FNO}+\mathrm{H}\right]^{+}:$164.15; found: 164.15 .

\subsection{Synthesis of 3-5(-Bromothiophen-2-yl)-2-(4-Fluorobenzoyl) Acrylonitrile (2)}

3-5(-bromothiophen-2-yl)-2-(4-fluorobenzoyl) acrylonitrile was synthesized by consulting the reported literature [35]. In a round bottom flask, 5-bromo-2-thiophenecarboxaldehy de (1.582 g, $8.28 \mathrm{mmol})$ and 4-fluorobenzoylacetonitrile (1.35 g, $8.28 \mathrm{mmol}, 1$ equiv.) were stirred in $50 \mathrm{~mL}$ degassed ethanol at room temperature under argon atmosphere for $1 \mathrm{~h}$. Thereafter, potassium tertiary butoxide, $\mathrm{t}-\mathrm{BuOK}(0.41 \mathrm{~g}, 3.72 \mathrm{mmol}, 0.45$ equiv. $)$ in $10 \mathrm{~mL}$ of ethanol was dropped in the reaction mixture and further subjected to stirring for $5 \mathrm{~h}$ at 298 K. Obtained yellow precipitates were filtered out, washed with deionized (DI) water and methanol. The purification of the crude product was carried out with the help of flash column chromatography using dichloromethane and hexane as eluents (DCM: hexane, 1:2 $v / v)$. The resulted dried solid was recrystallized with dichloromethane and ethyl acetate (DCM: EtOAc, 1:10 v/v) to obtain intermediate (2) as a light yellow crystal (yield 76.57\%, $2.13 \mathrm{~g}){ }^{1} \mathrm{H} \mathrm{NMR}\left(500 \mathrm{MHz}, \mathrm{CDCl}_{3}, \mathrm{ppm}\right) \delta: 8.18(\mathrm{~s}, 1 \mathrm{H}), 7.95(\mathrm{dd}, \mathrm{J}=8.7 \mathrm{~Hz}, 5.2 \mathrm{~Hz}, 2 \mathrm{H})$, $7.56(\mathrm{~d}, \mathrm{~J}=4.0 \mathrm{~Hz}, 1 \mathrm{H}), 7.2(\mathrm{~d}, \mathrm{~J}=4.0 \mathrm{~Hz}, 1 \mathrm{H}), 7.18(\mathrm{t}, \mathrm{J}=8.6 \mathrm{~Hz}, 2 \mathrm{H}) .{ }^{13} \mathrm{C}$ NMR $(100$ $\left.\mathrm{MHz}, \mathrm{CDCl}_{3}, \mathrm{ppm}\right) \delta$ : 186.39, 166.93, 164.89, 147.03, 138.76, 138.11, 131.98, 131.90, 131.77, 125.21, 117.57, 116.13, 115.95, 105.56. MS: $\mathrm{m} / \mathrm{z}$ calc. for $\left[\mathrm{C}_{14} \mathrm{H}_{7} \mathrm{BrFNOS}+\mathrm{H}\right]^{+}: 337.18$; found: 337.98 .

\subsection{Synthesis of 2-(4-Fluorobenzoyl)-3-(5"-hexyl-[2,2':5',2"-Terthiophen]-5-yl) Acrylonitrile, (H3T-4-FOP)}

5'-hexyl-2,2'-bithiophene-5-boronic acid pinacol ester (0.942 g, $2.50 \mathrm{mmol}), 3$-5(-bromo thiophen-2-yl)-2-(4-fluorobenzoyl) acrylonitrile (0.504 g, $3.75 \mathrm{mmol}, 1.5$ equiv.) and $5 \mathrm{~mol} \%$ $\mathrm{Pd}\left(\mathrm{PPh}_{3}\right)_{4}$ were stirred in toluene (anhydrous, $30 \mathrm{~mL}$ ). After $30 \mathrm{~min}, 2 \mathrm{M}$ potassium carbonate $\left(\mathrm{K}_{2} \mathrm{CO}_{3}\right)$ in $5 \mathrm{~mL}$ of water was introduced in the reaction and refluxed at $110{ }^{\circ} \mathrm{C}$ for $24 \mathrm{~h}$. Afterwards, the reaction mixture was allowed to cool at room temperature, washed with DI water and brine. The resulting organic phase was extracted with DCM, dried over $\mathrm{MgSO}_{4}$ and evaporated under vacuum conditions. The crude product was further purified by flash column chromatography with dichloromethane and hexane as eluents (DCM: hexane, 1:5 v/v) and dried in an oven. Thereafter, recrystallized twice with (DCM: EtOAc, 1:10 v/v) to obtain a bright red crystal (yield $63.21 \% 0.758 \mathrm{~g}) .{ }^{1} \mathrm{H} \mathrm{NMR}(500 \mathrm{MHz}$, $\left.\mathrm{CDCl}_{3}, \mathrm{ppm}\right) \delta: 8.25(\mathrm{~s}, 1 \mathrm{H}), 7.95(\mathrm{dd}, \mathrm{J}=5.2 \mathrm{~Hz}, 3.9 \mathrm{~Hz}, 2 \mathrm{H}), 7.70(\mathrm{~d}, \mathrm{~J}=4.3 \mathrm{~Hz}, 1 \mathrm{H}), 7.31$ $(\mathrm{d}, \mathrm{J}=2.3 \mathrm{~Hz}, 1 \mathrm{H}), 7.23(\mathrm{~d}, \mathrm{~J}=4.1 \mathrm{~Hz}, 1 \mathrm{H}), 7.18(\mathrm{t}, \mathrm{J}=8.6 \mathrm{~Hz}, 2 \mathrm{H}), 7.05(\mathrm{dd}, \mathrm{J}=6.0 \mathrm{~Hz}$, $3.8 \mathrm{~Hz}, 2 \mathrm{H}), 6.70(\mathrm{~d}, \mathrm{~J}=3.6 \mathrm{~Hz}, 1 \mathrm{H}), 6.79(\mathrm{t}, \mathrm{J}=7.6 \mathrm{~Hz}, 2 \mathrm{H}), 1.63(\mathrm{~m}, 4 \mathrm{H}), 1.33(\mathrm{~m}, 4 \mathrm{H})$, $0.88(\mathrm{t}, \mathrm{J}=6.8 \mathrm{~Hz}, 3 \mathrm{H}) .{ }^{13} \mathrm{C}$ NMR $\left(100 \mathrm{MHz} \mathrm{CDCl}_{3}, \mathrm{ppm}\right) \delta: 186.68,166.73,164.71,148.48$, $147.50,147.20,140.84,140.47,134.62,133.75,133.45,131.86,131.69,127.75,125.27,124.61$, $124.33,124.17,118.17,115.99,115.81,103.51,31.64,31.62,30.32,28.82,22.64,14.15 . \mathrm{MS}: \mathrm{m} / \mathrm{z}$ calc. for $\left[\mathrm{C}_{28} \mathrm{H}_{24} \mathrm{FNOS}_{3}+\mathrm{H}\right]^{+}: 505.69$; found: 506.45. Elemental analysis for $\mathrm{C}_{28} \mathrm{H}_{24} \mathrm{FNOS}_{3}$, calculated: C, 66.50; H, 4.78; F, 3.76; N, 2.77; O, 3.16; S, 19.02. Found: C, 66.67; H, 4.73; F, $3.72 ; \mathrm{N}, 2.79 ; \mathrm{O}, 3.15 ; \mathrm{S}, 18.89$.

\subsection{Assembly of BHJ-OSC Device}

In order to fabricate BJH-OSCs, indium tin oxide (ITO, Samsung electronics, $12-16 \Omega$ /sq) glass substrates were washed consecutively using DI water, detergent, acetone and isopropyl alcohol using an ultrasonic bath for $15 \mathrm{~min}$, followed by drying in an oven. A buffer layer of compact c- $\mathrm{TiO}_{2}$ layer [38] was first spin coated on cleaned ITO substrates at a scan rate of $3000 \mathrm{rpm}$ for $30 \mathrm{~s}$ and subsequently heated at $100{ }^{\circ} \mathrm{C}$ in a vacuum oven for $20 \mathrm{~min}$, followed by annealing at $450{ }^{\circ} \mathrm{C}$ in a closed furnace for $30 \mathrm{~min}$. Thereafter, the blend solutions were formulated in chlorobenzene by mixing $\mathrm{H} 3 \mathrm{~T}-4-\mathrm{FOP}$ and $\mathrm{PC}_{61} \mathrm{BM}$ in different weight ratios (H3T-4-FOP: $\mathrm{PC}_{61} \mathrm{BM}$; 1:1, 1:2, 1:3 w/w) under stirring at $60{ }^{\circ} \mathrm{C}$ for $4 \mathrm{~h}$ to obtain well mixed blend solution. H3T-4-FOP: $\mathrm{PC}_{61} \mathrm{BM}$ blend thin film was casted on $\mathrm{c}-\mathrm{TiO}_{2}$ layer at a scan rate of $\sim 2100 \mathrm{rpm}$ for $35 \mathrm{~s}$ and immediately subjected to annealing at $70{ }^{\circ} \mathrm{C}$ for 
$10 \mathrm{~min}$. Finally, a thin layer of gold ( $\mathrm{Au}, \sim 100 \mathrm{~nm}$ thickness) as top electrode was thermally evaporated over the $\mathrm{ITO} / \mathrm{c}-\mathrm{TiO}_{2} / \mathrm{H} 3 \mathrm{~T}-4-\mathrm{FOP}: \mathrm{PC}_{61} \mathrm{BM}$ to complete the device configuration of ITO/c-TiO $2 / \mathrm{H} 3 \mathrm{~T}-4-\mathrm{FOP}: \mathrm{PC}_{61} \mathrm{BM} / \mathrm{Au}$. In order to check the reproducibility, 20 devices of each BJH-OSCs were tested for extracting the performance of the devices.

\subsection{Characterizations}

Fourier transform-infrared (FTIR) spectroscopy analysis was investigated using a FTIR-4100 (JASCO, Tokyo, Japan) spectrometer with a solid pellet of $\mathrm{KBr}$ as a reference. JEOL FT-NMR $\left({ }^{1} \mathrm{H}\right.$ at $500 \mathrm{MHz}$ and ${ }^{13} \mathrm{C}$ at $\left.125 \mathrm{MHz}\right)$ spectrophotometer was used to investigate the NMR data of the synthesized H3T-4-FOP SOM in deuterated chloroform $\left(\mathrm{CDCl}_{3}\right)$ as a reference solvent. The chemical shift $(\delta)$ values were measured in ppm referred to internal standard of tetramethyl silane (TMS). The mass spectra (MS) were determined by XEVO TQ-S spectrometry. The UV-Vis absorption and photoluminescence (PL) spectra were characterized by V-670 (JASCO, Japan) spectrophotometer and FP6500 (JASCO, Japan) spectrofluorometer, respectively. Thermogravimetric analysis (TGA) and differential scanning calorimetry (DSC) were measured at a scan rate of $10^{\circ} \mathrm{C} / \mathrm{min}$ under nitrogen gas atmosphere using with a thermal analyzer (TA) instrument Q-50. The cyclic voltammogram (CV) was elucidated with an electrochemical system (WPG 100 Potentiostat/Galvanostat, WonATech) comprising of H3T-4-FOP modified glassy carbon as working electrode, a reference saturated calomel electrode (SCE) and a platinum wire as a counter electrode in $0.1 \mathrm{M}$ tetrabutylammonium hexaflourophosphate $\left(\mathrm{TBAPF}_{6}\right)$ in acetonitrile as the supporting electrolyte. The surface morphology of the fabricated thin film was characterized by atomic force microscopy (AFM) in tapping mode using AFM Nanoscope IV Digital Instrument, Santa Barbara, USA. For the evaluation of photovoltaic parameters, the typical J-V curves of the fabricated BHJ-OSCs were measured under one sun, i.e., AM 1.5G $\left(100 \mathrm{~mW} / \mathrm{cm}^{2}\right)$ which was maintained by using $1000 \mathrm{~W}$ metal halide lamp (Phillips, Amsterdam, The Netherlands) and one sun intensity was calibrated with a Si photo detector obtained from NREL (Golden, CO, USA).

\section{Results and Discussion}

\subsection{Thermal Properties of H3T-4-FOP}

TGA and DSC, with respect to change in temperature $\left(10^{\circ} \mathrm{C} / \mathrm{min}\right)$ under an inert atmosphere, were carried out to investigate the thermal stability and the flow of energy in the molecule, respectively. H3T-4-FOP SOM shows good thermal stability and the decomposition temperature (Td) with $5 \%$ weight loss above $\sim 335^{\circ} \mathrm{C}$, as shown in Figure 1a. Such thermally stable chromophores are suitable for device fabrication without degrading the active layer in BHJ-OSCs. From the DSC thermogram of Figure 1b, two melting peaks are observed at $\sim 118{ }^{\circ} \mathrm{C}$ and $\sim 160{ }^{\circ} \mathrm{C}$ with no clear crystalline peak. We assume that the 4-fluorobenzoylacetonitrile moiety might be responsible for the amorphous behavior of H3T-4-FOP SOM.

(a)

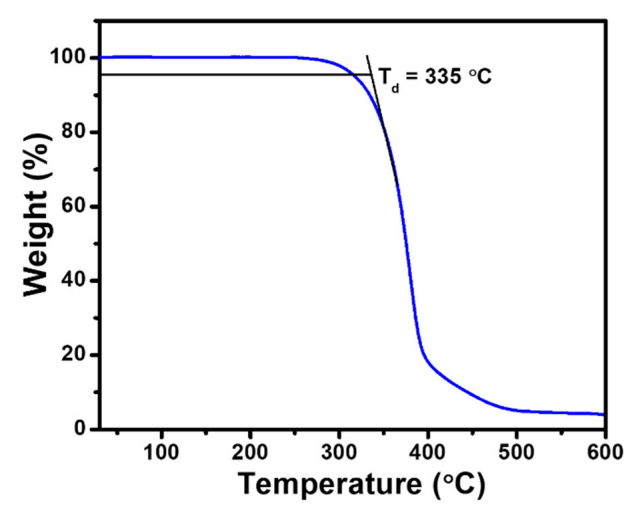

(b)



Figure 1. (a) Thermogravimetric analysis (TGA) and (b) differential scanning calorimetry (DSC) plots of H3T-4-FOP. 


\subsection{Optical Properties of H3T-4-FOP}

The optical properties of H3T-4-FOP SOM were investigated by UV-Vis and PL spectroscopy in a chloroform solvent, thin films and blend thin films. The representative spectra of H3T-4-FOP SOM are shown in Figure 2a,b and the obtained data are summarized in Table 1. H3T-4-FOP SOM exhibits good solubility in chloroform, tetrahydrofuran (THF) and chlorobenzene solvents. In the chloroform solvent, H3T-4-FOP SOM displays a broad absorption band in the range of $\sim 320 \mathrm{~nm}$ to $\sim 620 \mathrm{~nm}$ with an absorption maximum ( $\lambda$ max) at $\sim 495 \mathrm{~nm}$, corresponding to $\pi-\pi^{*}$ (HOMO to LUMO) transitions of the conjugated $\pi$ system, as shown in Figure 2a. However, the H3T-4-FOP thin film poses a red shift $(\sim 10 \mathrm{~nm})$ with $\lambda_{\max }$ at $\sim 505 \mathrm{~nm}$ which is mainly caused by $\pi-\pi$ stacking and an extended terminal hexyl side chain which affects the intermolecular interaction and aggregation in solid state. Such type of absorption properties of small molecules with a methyl, ethyl, hexyl and dodecyl chain is discussed by Min et al. when moving from solution to a thin film [39]. The optical band gap of $\sim 2.01 \mathrm{eV}$ for H3T-4-FOP SOM is calculated from absorption onset equation $\mathrm{E}_{\mathrm{g}}{ }^{\mathrm{opt}}=1240 / \lambda_{\text {onset }}$ where $\lambda_{\text {onset }}$ is in $\mathrm{nm}$ and $\mathrm{E}_{\mathrm{g}}$ in $\mathrm{eV}$ [40]. The photoluminescence spectroscopy of H3T-4-FOP SOM is performed in a chloroform solution and thin film coated ITO substrates. A strong and sharp emission band is observed at $\sim 625 \mathrm{~nm}$ in the solution which is remarkably red-shifted to $\sim 670 \mathrm{~nm}$ in the thin film state, as seen from Figure $2 \mathrm{~b}$. Furthermore, the red shifted PL spectrum is observed moving from solution to thin film state which might be due to an orientation of the molecule in head-to-tail fashion. Thus, negative coulombic coupling is originated, resulting in J-type aggregation (Bathochromic shift) [41]. The absorption and emission of blend thin films (H3T-4-FOP: $\left.\mathrm{PC}_{61} \mathrm{BM}, w / w\right)$ are further characterized to investigate the effect of photon absorption, as represented in Figure 3a,b. The blend thin film covers the absorption range of $\sim 350 \mathrm{~nm}$ to $\sim 650 \mathrm{~nm}$, representing a good photon harvesting material for BHJ-OSCs. From Figure $3 \mathrm{a}$, the intense absorption signal is observed for H3T-4-FOP: $\mathrm{PC}_{61} \mathrm{BM}(1: 2, w / w)$, which might be due to uniform, well-mixed and smooth surface morphology of the thin film. It is well known that the concentration of donor and acceptor materials in blend thin film plays a critical role in improving the light absorption and charge extraction for high performance solar devices. In our case, the H3T-4-FOP:PC ${ }_{61} \mathrm{BM}(1: 2, w / w)$ ratio presents a high absorption intensity due to the complete dissolution of donor-acceptor materials in the chlorobenzene solvent which might induce the film uniformity and transparency with interconnected domains. To further understand the charge transfer behavior in donor-acceptor blends, Figure $3 \mathrm{~b}$ exhibits the PL emission spectra of thin films of different blend ratios. Herein, the presence of the 4-fluorobenzoylacetonitrile acceptor moiety might be responsible for the fast emission due to the strong electron accepting nature and hydrogen bond interaction. The quenching effect is observed in all blend thin films but nearly complete quenching (quenching of $\sim 97 \%$ ) occurred in H3T-4-FOP: $\mathrm{PC}_{61} \mathrm{BM}(1: 2, w / w)$. However, slightly lower quenching of $\sim 93 \%$ was seen for H3T-4-FOP: $\mathrm{PC}_{61} \mathrm{BM}(1: 3, w / w)$ which clearly reflects the modest emission properties of H3T-4-FOP: $\mathrm{PC}_{61} \mathrm{BM}(1: 2, w / w)$. Herein, high PL quenching in H3T-4-FOP: $\mathrm{PC}_{61} \mathrm{BM}(1: 2, w / w)$ ensures a smooth and uniform surface with ordered phase separation of donor and acceptor which might reduce the charge recombination within the exciton diffusion length and, therefore, induces the exciton-dissociation at the donor acceptor interfaces [42,43]. 



Figure 2. (a) UV-Vis absorption and (b) photoluminescence spectra of H3T-4-FOP SOM in chloroform solvent and in thin film.

Table 1. Optical and electrochemical values of H3T-4-FOP SOM.

\begin{tabular}{cccccccc}
\hline Chromophore & $\lambda_{\max }{ }^{a}(\mathbf{n m})$ & $\lambda_{\max }{ }^{b}(\mathbf{n m})$ & $\lambda_{\max }{ }^{c}(\mathbf{n m})$ & $\lambda_{\max }{ }^{d}(\mathbf{n m})$ & $\begin{array}{c}\text { HOMO } \\
(\mathbf{e V})\end{array}$ & $\begin{array}{c}\text { LUMO }^{\mathrm{f}} \\
(\mathbf{e V})\end{array}$ & $\mathrm{Eg}_{\mathrm{g}} \mathbf{o p t g}_{(\mathrm{eV})}$ \\
\hline H3T-4-FOP & 495 & 505 & 625 & 670 & -5.27 & -3.26 & 2.01 \\
\hline
\end{tabular}

${ }^{a}$ Absorption in chloroform solution. ${ }^{b}$ Absorption of thin film on ITO. ${ }^{c}$ Photoluminescence in chloroform solution. ${ }^{\mathrm{d}}$ Photoluminescence in thin film on ITO. ${ }^{\text {e }}$ Calculated from the oxidation onset value of cyclic voltammogram. ${ }^{\mathrm{f}}$ Obtained from equation; LUMO $=\mathrm{HOMO}+$ $\mathrm{E}_{\mathrm{g}}{ }^{\text {opt }}, \mathrm{g}$ Optical band gap derived by the equation $\mathrm{E}_{\mathrm{g}}{ }^{\text {opt }}=1240 / \lambda_{\text {edge }}$.
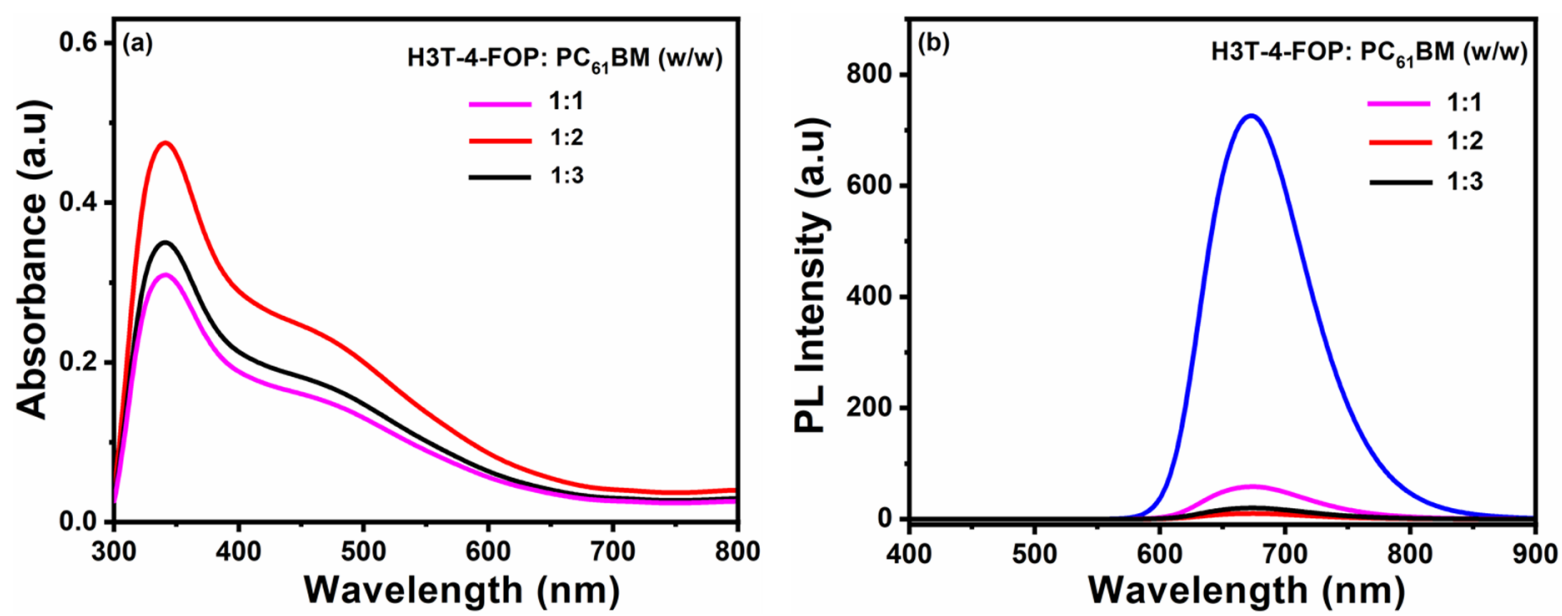

Figure 3. (a) UV-Vis absorption and (b) photoluminescence spectra of blend films of H3T-4-FOP: PC 61 BM in 1:1 (w/w), $1: 2(w / w)$, and $1: 3(w / w)$ ratios.

\subsection{Electrochemical Properties of H3T-4-FOP}

Figure 4a shows the electrochemical properties of H3T-4-FOP SOM, as investigated by the cyclic voltammetry $(\mathrm{CV})$ method, using an oxidation onset potential value of $+0.25 \mathrm{~V}$. Freshly prepared $0.1 \mathrm{M}$ tetrabutylammonium hexaflouro-phosphate $\left(\mathrm{TBAPF}_{6}\right)$ was incorporated in acetonitrile and $\mathrm{CV}$ measurements were performed with a scan rate of $100 \mathrm{mV} / \mathrm{s}$, using $\mathrm{Fc} / \mathrm{Fc}^{+}$as an external reference. From the $\mathrm{CV}$ measurements, $\mathrm{HOMO}$ and LUMO energies were estimated as $-5.27 \mathrm{eV}$ and $-3.26 \mathrm{eV}$, respectively, from oxidation onset and optical band gap value by using the formula for LUMO energy; LUMO = HOMO $+\mathrm{Eg}^{\text {opt }}$ [44]. Our newly designed H3T-4-FOP SOM exhibits a suitable frontier orbital energy 
level which is possibly due to the presence of three electron-accepting functional groups, i.e., keto $(\mathrm{CO})$, cyano $(\mathrm{CN})$, and fluoro $(\mathrm{F})$ in the 4 -fluorobenzoylacrylonitrile acceptor unit (Figure $4 \mathrm{~b}$ ). The HOMO and LUMO energy levels of H3T-4-FOP donor are, respectively, higher than the classical $\mathrm{PC}_{61} \mathrm{BM}$ acceptor material to produce enough driving force for an exciton dissociation.

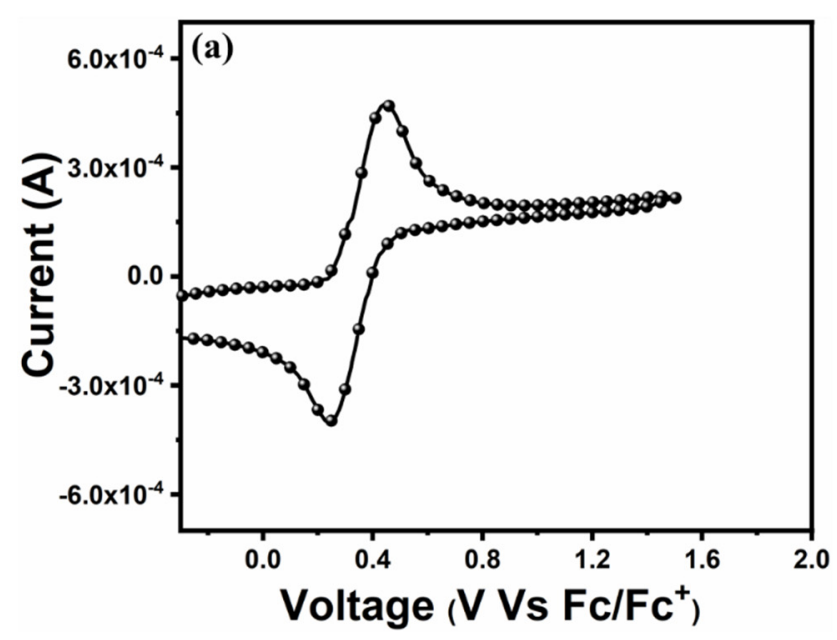

(b)

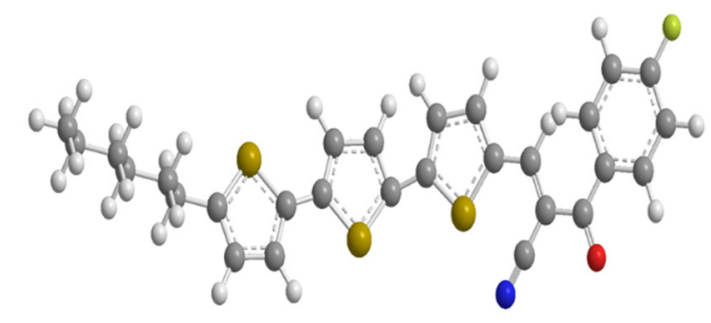

Figure 4. (a) Cyclic voltammogram (CV) and (b) 3D structure of H3T-4-FOP SOM.

The energy levels of the fabricated BHJ-OSCs with H3T-4-FOP: PC $_{61} \mathrm{BM}$ active layer are shown in Figure 5a. The electrochemical and optical properties of the newly synthesized H3T-4-FOP match well with the $\mathrm{PC}_{61} \mathrm{BM}$ acceptor energy level. The designed $\mathrm{SOM}$ is applied for fabricating $\mathrm{BHJ}-\mathrm{OSC}$ s as the donor material with the $\mathrm{PC}_{61} \mathrm{BM}$ acceptor. The photovoltaic performance of an active layer with different blend ratios (H3T-4-FOP:PC ${ }_{61} \mathrm{BM}$, $1: 1,1: 2,1: 3, w / w)$ were tested by measuring the I-V curves under a light illumination at $100 \mathrm{~mW} / \mathrm{cm}^{2}$ (AM 1.5), as shown in Figure 5b. BHJ-OSC device with H3T-4-FOP: PC ${ }_{61}$ BM $(1: 2, w / w)$ active layer reveals a promising PCE of $\sim 4.38 \%$, a high Jsc $=\sim 11.18 \mathrm{~mA} / \mathrm{cm}^{2}$, $\mathrm{Voc}=0.782 \mathrm{~V}$ and $\mathrm{FF}$ of $50 \%$. It is expected that due to the high absorption and scattering behavior, the fabricated BHJ-OSC exhibits a promising Jsc and Voc. Moreover, the improved Jsc and photovoltaic performance of the (H3T-4-FOP: PC $\left._{61} \mathrm{BM}, 1: 2 w / w\right)$ active layer might be associated with smooth film morphology (discussed in the next section) and a fast intermolecular charge transfer (ICT) between H3T-4-FOP and $\mathrm{PC}_{61} \mathrm{BM}$ which occurs due to the introduction of multifunctional electron deficient groups in the acceptor unit [45]. In support, the introduction of the hexyl side chain in the donor molecule further reduces the interaction between the donor-acceptor interfaces which results in suppressing the charge recombination and hence, improves the Voc [42]. Significantly, without any additives or promotors in the active layer, the FF of the fabricated BHJ-OSCs shows relatively a high value which credits to a suitable morphology and high charge carrier mobility [46]. However, the fabricated BHJ-OSCs with H3T-4-FOP:PC ${ }_{61}$ BM $(1: 1, w / w)$ and H3T-4-FOP: $\mathrm{PC}_{61} \mathrm{BM}(1: 3, w / w)$ demonstrate lower photovoltaic parameters, as summarized in Table 2. For the H3T-4-FOP: $\mathrm{PC}_{61} \mathrm{BM}(1: 1, w / w)$ thin film, it is expected that the creation of small barriers at the interfaces between the donor and acceptor units during the fabrication of $\mathrm{BHJ}$-OSCs might be responsible for the occurrence of the high recombination of exciton, which resulted in a low FF [47]. The obtained photovoltaic parameters were compared with the existing research [48-51], as demonstrated in Table 3. 
(a)
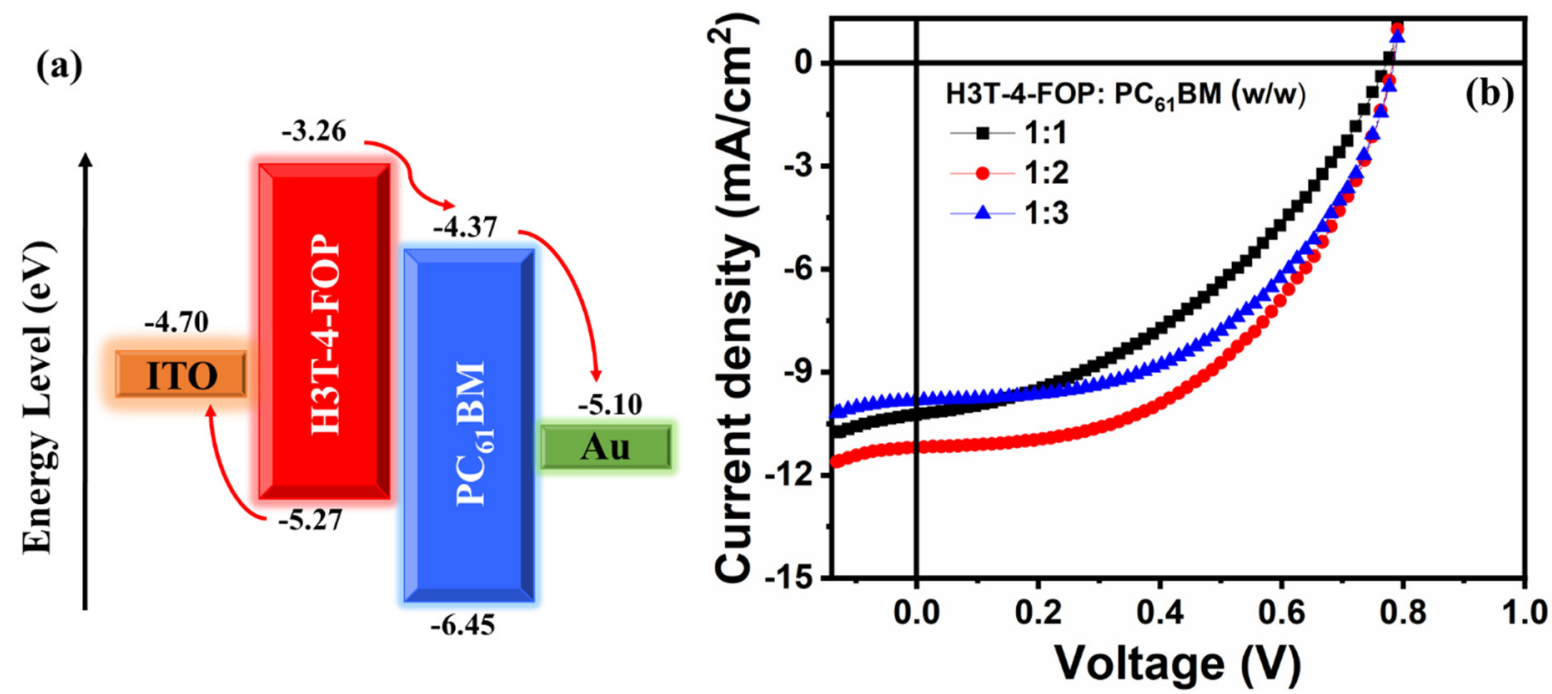

Figure 5. (a) Energy level diagram and (b) J-V curve of fabricated bulk heterojunction organic solar cells (BHJ-OSCs) with the active layer of H3T-4-FOP: $\mathrm{PC}_{61} \mathrm{BM}$ at various ratios $(1: 1 w / w, 1: 2 w / w$, and 1:3 w/w).

Table 2. Photovoltaic parameters of the fabricated BHJ-OSCs devices with H3T-4-FOP:PC ${ }_{61} \mathrm{BM}_{\text {active }}$ layer.

\begin{tabular}{ccccc}
\hline H3T-4-FOP: $\mathbf{P C}_{\mathbf{6 1}} \mathbf{B M}$ & $\mathbf{V}_{\mathbf{o c}}(\mathbf{V})$ & $\mathbf{J}_{\mathbf{s c}}\left(\mathbf{m A} \mathbf{A} \mathbf{c m}^{\mathbf{2}}\right)$ & $\mathbf{F F} \mathbf{( \% )}$ & PCE (\%) \\
\hline $1: 1(w / w)$ & 0.772 & 10.22 & 41 & 3.21 \\
$1: 2(w / w)$ & 0.782 & 11.18 & 50 & 4.38 \\
$1: 3(w / w)$ & 0.782 & 9.83 & 51 & 3.91 \\
\hline
\end{tabular}

Table 3. Comparative study of fabricated BHJ-OSCs with different organic chromophores and H3T-4-FOP.

\begin{tabular}{|c|c|c|c|c|c|}
\hline Organic Chromophores & $\mathrm{V}_{\mathrm{oc}}(\mathrm{V})$ & $\mathrm{J}_{\mathrm{sc}}\left(\mathrm{mA} / \mathrm{cm}^{2}\right)$ & FF (\%) & PCE (\%) & Reference \\
\hline RTh-NR:PC 61 BM & 0.59 & 8.70 & 32 & 1.65 & 34 \\
\hline RT-BSe-F:PC 60 BM & 0.71 & 12.56 & 42 & 3.75 & 35 \\
\hline OMe-BBTz:PC 61 BM & 0.69 & 8.71 & 58 & 3.53 & 48 \\
\hline DCAE7T-F1:PC 61 BM & 0.83 & 5.55 & 50 & 2.26 & 49 \\
\hline DFP-BT-TPA:PC ${ }_{71} \mathrm{BM}$ & 0.90 & 6.12 & 39 & 2.17 & 50 \\
\hline PBDTFT-ttTPD:PC ${ }_{71} \mathrm{BM}$ & 0.79 & 8.57 & 48 & 3.27 & 51 \\
\hline H3T-4-FOP:PC 61 BM $(1: 1, w / w)$ & 0.772 & 10.22 & 41 & 3.21 & This work \\
\hline H3T-4-FOP:PC 61 BM $(1: 2, w / w)$ & 0.782 & 11.18 & 50 & 4.38 & This work \\
\hline H3T-4-FOP:PC 61 BM $(1: 3, w / w)$ & 0.782 & 9.83 & 51 & 3.91 & This work \\
\hline
\end{tabular}

The network of the donor-acceptor interface of an active layer affects the charge separation and extraction efficiency [52], thus, the morphological features of the blend thin films are studied by atomic force microscopy (AFM). The height and 3D images of H3T-4-FOP: $\mathrm{PC}_{61} \mathrm{BM}$ blend films are shown in Figure 6a-f. AFM images clearly indicate the good miscibility of the donor and acceptor moieties. A relatively high mean-square roughness (Rrms) of $\sim 8.03 \mathrm{~nm}$ is observed in H3T-4-FOP: $\mathrm{PC}_{61} \mathrm{BM}(1: 1, w / w)$ ratio, as seen in Figure $6 \mathrm{a}, \mathrm{b}$, whereas a uniform morphology with an Rrms value of $\sim 4.77 \mathrm{~nm}$ is observed for the H3T-4-FOP: $\mathrm{PC}_{61} \mathrm{BM}(1: 2, w / w)$ blend thin film which favors the nanoscale phase separation and efficient exciton dissociation and, thus, attributes to relatively higher Jsc, Voc, and device performance values based on the H3T-4-FOP: $\mathrm{PC}_{61} \mathrm{BM}(1: 2, w / w)$ active layer. Overall, under optimized conditions, the blend thin film of H3T-4-FOP: $\mathrm{PC}_{61} \mathrm{BM}(1: 2$, $w / w)$ demonstrates fine and evenly distributed domains with a continuous interpenetrating network without the existence of large aggregates. 
(a)

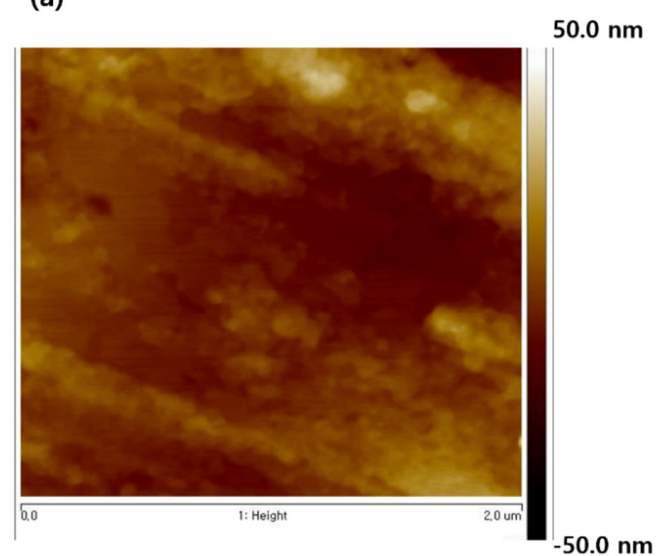

(c)

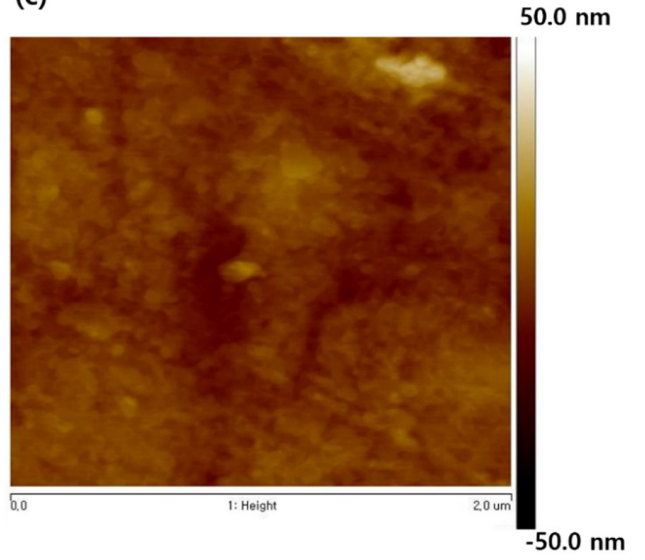

(e)

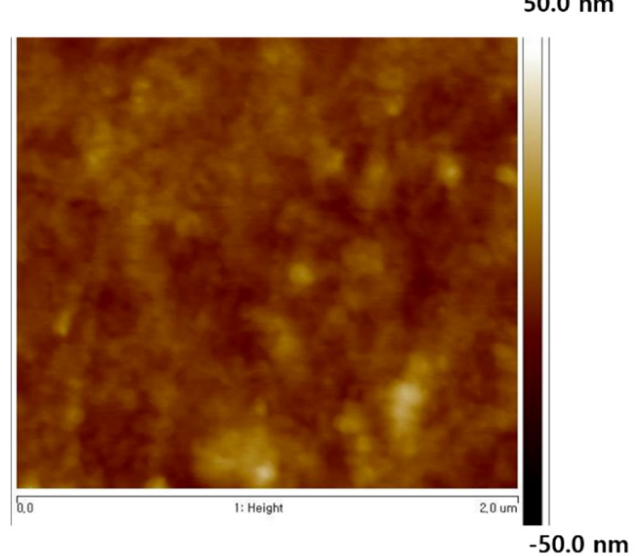

(b)

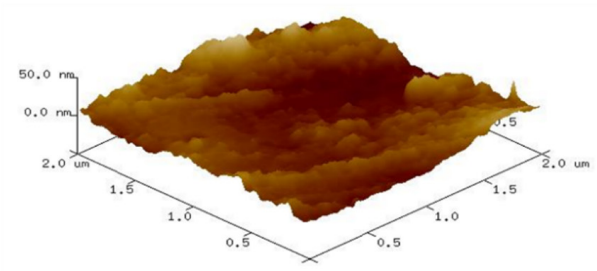

(d)

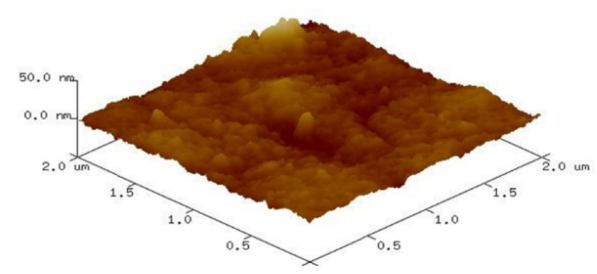

(f)

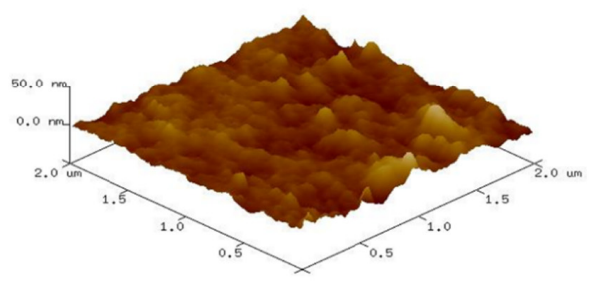

Figure 6. Atomic force microscopy (AFM) at topographical and 3D modes of (a,b) 1:1, w/w and (c,d) 1:2, w/w and (e,f) of H3T-4-FOP:PC ${ }_{61}$ BM blend thin films.

\section{Conclusions}

A new and novel 4-fluorobenzoylacetonitrile based $\pi$-conjugated SOM, H3T-4-FOP, was synthesized and utilized as a photoactive organic donor for the fabrication of $\mathrm{BHJ}-$ OSCs. The synthesized SOM is soluble in common organic solvents due to the presence of a terminal hexyl side chain. The combined spectroscopic and electrochemical investigations revealed that H3T-4-FOP SOM-due to the existence of $\pi-\pi^{*}$ and an ICT band-leads an extension of the absorption spectral range. The fabricated BHJ-OSCs with a H3T-4FOP: $\mathrm{PC}_{61} \mathrm{BM}(1: 2, w / w)$ active layer shows a relatively high PCE of $\sim 4.38 \%$ with a Jsc of $\sim 11.18 \mathrm{~mA} / \mathrm{cm}^{2}$, Voc of $0.782 \mathrm{~V}$ and FF of $\sim 50 \%$. Significantly, the better performance 
and current density of the H3T-4-FOP: $\mathrm{PC}_{61} \mathrm{BM}(1: 2, w / w)$ active layer as compared to other blend thin films, can be attributed to better packing, favorable orientation, homogeneous blending, and uniform thin film morphology. The obtained molecular properties and promising device performance support the future designing of multifunction groups containing 4-fluorobenzoylacetonitrile based SOMs for the fabrication of high performance BHJ-OSCs.

Author Contributions: S.A. (Shabaz Alam); conceptualization, formal analysis, investigation and methodology, A. and M.S.A.; software, validation, resources, data curation, E.-B.K. and S.A. (Shabaz Alam); writing—original draft preparation, visualization, S.A. (Sadia Ameen); writing-review and editing, supervision, H.-S.S.; project administration, funding acquisition. All authors have read and agreed to the published version of the manuscript.

Funding: This research received no external funding.

Institutional Review Board Statement: Not applicable.

Informed Consent Statement: Not applicable.

Data Availability Statement: Not applicable.

Acknowledgments: This work is fully supported by the National Research Foundation of Korea (NRF) grant funded by the Korea government (MSIT) (NRF2019R1F1A1063999). This research is supported by Korea Basic Science Institute under the R \& D Program (Project No.: D010710) supervised by the Ministry of Science and ICT. We also acknowledge the Korea Basic Science Institute (KBSI), Jeonju branch, for utilizing the research supported facilities. This work is supported by Jeonbuk National University, 2020.

Conflicts of Interest: The authors declare no conflict of interest.

\section{References}

1. Kippelen, B.; Bredas, J.-L. Organic Photovoltaics. Energy Environ. Sci. 2009, 2, 251-261. [CrossRef]

2. Brabec, C.J. Organic photovoltaics: Technology and market. Sol. Energy Mater. Sol. Cells 2004, 83, 273-292. [CrossRef]

3. Heeger, A.J. Semiconducting polymers: The third generation. Chem. Soc. Rev. 2010, 39, 2354-2371. [CrossRef] [PubMed]

4. Darling, S.B.; You, F. The case for organic photovoltaic. RSC Adv. 2013, 3, 17633-17648. [CrossRef]

5. Bagher, A.M. Comparison of organic solar cells and inorganic solar cells. Int. J. Renew. Sustain. Energy 2014, 3, 53-58. [CrossRef]

6. Ameen, S.; Akhtar, M.S.; Nazim, M.; Nazeeruddin, M.K.; Shin, H.-S. Stable perovskite solar cells using thiazolo [5,4-d]thiazole-core containing hole transporting material. Nano Energy 2018, 49, 372-379. [CrossRef]

7. Emmott, C.J.M.; Rohr, J.A.; Quiles, M.C.; Kirchartz, T.; Urbina, A.; Daukes, N.J.E.; Nelson, J. Organic photovoltaic greenhouses: A unique application for semi-transparent PV? Energy Environ. Sci. 2015, 8, 1317-1328. [CrossRef]

8. Kang, H.; Kim, G.; Kim, J.; Kwon, S.; Kim, H.; Lee, K. Bulk-Heterojunction Organic Solar Cells: Five Core Technologies for Their Commercialization. Adv. Mater. 2016, 28, 7821-7861. [CrossRef]

9. Dennler, G.; Scharber, M.C.; Brabec, C.J. Polymer-fullerene bulk-heterojunction solar cells. Adv. Mater. 2009, 21, 1323-1338. [CrossRef]

10. Zhang, J.; Tan, H.S.; Guo, X.; Facchetti, A.; Yan, H. Material insights and challenges for non-fullerene organic solar cells based on small molecular acceptors. Nat. Energy 2018, 3, 720. [CrossRef]

11. Umeyama, T.; Igarashi, K.; Sasada, D.; Tamai, Y.; Ishida, K.; Koganezawa, T.; Ohtani, S.; Tanaka, K.; Ohkita, H.; Imahori, H. Efficient light-harvesting, energy migration, and charge transfer by nanographene-based nonfullerene small-molecule acceptors exhibiting unusually long excited-state lifetime in the film state. Chem. Sci. 2020, 11, 3250. [CrossRef]

12. Gasparini, N.; Salvador, M.; Strohm, S.; Heumueller, T.; Levchuk, I.; Wadsworth, A.; Bannock, J.H.; de Mello, J.C.; Egelhaaf, H.J.; Baran, D.; et al. Burn-in Free Nonfullerene-based Organic Solar. Cells Adv. Energy Mater. 2017, 7, 1700770. [CrossRef]

13. Liu, Q.; Jiang, Y.; Jin, K.; Qin, J.; Xu, J.; Li, W.; Xiong, J.; Liu, J.Z.; Xiao, Z.; Sun, K.; et al. 18\% efficiency organic solar cells. Sci. Bull. 2020, 65, 272-275. [CrossRef]

14. Ma, X.; Wang, J.; Gao, J.; Hu, Z.; Xu, C.; Zhang, X.; Zhang, F. Achieving 17.4\% Efficiency of Ternary Organic Photovoltaics with Two Well-Compatible Nonfullerene Acceptors for Minimizing Energy Loss. Adv. Energy Mater. 2020, 10, 2001404. [CrossRef]

15. Zhan, L.; Li, S.; Lau, T.-K.; Cui, Y.; Lu, X.; Shi, M.; Li, C.-Z.; Li, H.; Hou, J.; Chen, C. Over 17\% efficiency ternary organic solar cells enabled by two non-fullerene acceptors working in an alloy-like model. Energy Environ. Sci. 2020, 13, 635-645. [CrossRef]

16. Lin, Y.; Nugraha, M.I.; Firdaus, Y.; Scaccabarozzi, A.D.; Anies, F.; Emwas, A.-H.; Yengel, E.; Zheng, X.; Liu, J.; Wahyudi, W.; et al. A simple n-dopant derived from diquat boosts the efficiency of organic solar cells to 18.3\%. ACS Energy Lett. 2020, 5, 3663-3671. [CrossRef]

17. Hu, D.; Yang, Q.; Chen, H.; Wobben, F.; Corre, V.M.L.; Singh, R.; Liu, T.; Ma, R.; Tang, H.; Koster, L.J.A.; et al. 15.34\% efficiency all-small-molecule organic solar cells with an improved fill factor enabled by a fullerene additive. Energy Environ. Sci. 2020, 13, 2134-2141. [CrossRef] 
18. Zhou, R.; Jiang, Z.; Yang, C.; Yu, J.; Feng, J.; Adil, M.A.; Deng, D.; Zou, W.; Zhang, J.; Lu, K.; et al. All-small-molecule organic solar cells with over 14\% efficiency by optimizing hierarchical Morphologies. Nat. Comm. 2019, 10, 5393. [CrossRef]

19. Lee, H.; Mun, J.; Nguyen, N.N.; Rho, J.; Cho, K. Open-circuit voltage of organic solar cells: Effect of energetically and spatially non uniform distribution of molecular energy levels in the photoactive layer. Nano Energy 2020, 78, 105336. [CrossRef]

20. Clarke, T.M.; Durrant, J.R. Charge photogeneration in organic solar cells. Chem. Rev. 2010, 110, 6736-6767. [CrossRef]

21. Yang, B.; Guo, F.; Yuan, Y.; Xiao, Z.; Lu, Y.; Dong, Q.; Huang, J. Solution-Processed Fullerene-Based Organic Schottky Junction Devices for Large-Open-Circuit-Voltage Organic Solar Cells. Adv. Mater. 2013, 25, 572-577. [CrossRef] [PubMed]

22. Ecker, B.; Nolasco, J.C.; Pallares, J.; Marsal, L.F.; Posdorfer, J.; Parisi, J.; Von Hauff, E. Degradation Effects Related to the Hole Transport Layer in Organic Solar Cells. Adv. Funct. Mater. 2011, 21, 2705-2711. [CrossRef]

23. Tamura, H.; Tsukada, M. Role of intermolecular charge delocalization on electron transport in fullerene aggregates. Phys. Rev. $B$ 2012, 85, 054301. [CrossRef]

24. Swick, S.M.; Alzola, J.M.; Sangwan, V.K.; Amsterdam, S.H.; Zhu, W.; Jones, L.O.; Riggs, N.P.; Facchetti, A.; Kohlstedt, K.L.; Schatz, G.C.; et al. Fluorinating $\pi$-Extended Molecular Acceptors Yields Highly Connected Crystal Structures and Low Reorganization Energies for Efficient Solar Cells. Adv. Energy Mater. 2020, 10, 2000635. [CrossRef]

25. An, N.; Cai, Y.; Wu, H.; Tang, A.; Zhang, K.; Hao, X.; Ma, Z.; Guo, Q.; Ryu, H.S.; Woo, H.Y.; et al. Solution-Processed Organic Solar Cells with High Open-Circuit Voltage of 1.3 V and Low Non-Radiative Voltage Loss of 0.16 V. Adv. Mater. 2002, 10, 2002122. [CrossRef] [PubMed]

26. Li, Y.; Jia, Z.; Zhang, Q.; Wu, Z.; Qin, H.; Yang, J.; Wen, S.; Woo, H.Y.; Ma, W.; Yang, R.; et al. Toward Efficient All-Polymer Solar Cells via Halogenation on Polymer Acceptors. Appl. Mater. Interfaces 2020, 12, 33028-33038. [CrossRef]

27. Leclerc, N.; Chávez, P.; Ibraikulov, O.A.; Heiser, T.; Lévêque, P. Impact of backbone fluorination on $\pi$-conjugated polymers in organic photovoltaic devices: A review. Polymers 2016, 8, 11. [CrossRef]

28. Zhou, R.; Xia, B.; Li, H.; Wang, Z.; Yang, Y.; Zhang, J.; Laursen, B.W.; Lu, K.; Wei, Z. Fluorination Induced Donor to Acceptor Transformation in A1-D-A2-D-A1 Type Photovoltaic Small Molecules. Front. Chem. 2018, 6, 384. [CrossRef]

29. Wang, J.L.; Liu, K.K.; Yan, J.; Wu, Z.; Liu, F.; Xiao, F.; Chang, Z.F.; Wu, H.B.; Cao, Y.; Russel, T.P. Series of Multifluorine Substituted Oligomers for Organic Solar Cells with Efficiency over $9 \%$ and Fill Factor of 0.77 by Combination Thermal and Solvent Vapor Annealing. J. Am. Chem. Soc. 2016, 138, 7687-7697. [CrossRef]

30. Ameen, S.; Rub, M.A.; Kosa, S.A.; Alamry, K.A.; Akhtar, M.S.; Shin, H.-S.; Seo, H.-K.; Asiri, A.M.; Nazeeruddin, M.K. Perovskite solar cells: Influence of hole transporting materials on power conversion efficiency. ChemSusChem 2016, 9, 10-27. [CrossRef]

31. Nilsson, S.; Bernasik, A.; Budkowski, A.; Moons, E. Morphology and phase segregation of spin-casted films of polyfluorene/PCBM blends. Macromolecules 2007, 40, 8291-8301. [CrossRef]

32. Matsumoto, F.; Iwai, T.; Moriwaki, K.; Takao, Y.; Ito, T.; Mizuno, T.; Ohno, T. Controlling the Polarity of Fullerene Derivatives to Optimize Nanomorphology in Blend Films. ACS Appl. Mater. Interfaces 2016, 8, 4803-4810. [CrossRef]

33. Chen, X.; Feng, H.; Lin, Z.; Jiang, Z.; He, T.; Yin, S.; Wan, X.; Chen, Y.; Zhang, Q.; Qiu, H. Impact of end-capped groups on the properties of dithienosilole-based small molecules for solution-processed organic solar cells. Dyes Pigments 2017, 147, 183-189. [CrossRef]

34. Nazim, M.; Abdullah; Akhtar, M.S.; Kim, E.-B.; Shin, H.-S.; Ameen, S. Underlying effects of diiodooctane as additive on the performance of bulk heterojunction organic solar cells based small organic molecule of isatin-core moiety. Synth. Met. 2020, 261, 116304. [CrossRef]

35. Abdullah; Kim, E.-B.; Akhtar, M.S.; Shin, H.-S.; Ameen, S. Benzoselenadiazole-core asymmetric D-A-A small molecule for solution processed bulk heterojunction organic solar cells. Int. J. Energy Res. 2020, 1, 1-12. [CrossRef]

36. Shen, J.; Yang, D.; Liu, Y.; Qin, S.; Zhang, J.; Sun, J.; Liu, C.; Liu, C.; Zhao, X.; Chu, C.; et al. Copper-Catalyzed Aerobic Oxidative Coupling of Aromatic Alcohols and Acetonitrile to $\beta$-Ketonitriles. Org. Lett. 2014, 16, 350-353. [CrossRef] [PubMed]

37. Zou, Y.; Peng, B.; Liu, B.; Li, Y.; He, Y.; Zhou, K.; Pan, C. Conjugated Copolymers of Cyano substituted Poly(p-phenylene vinylene) with Phenylene Ethynylene and Thienylene Vinylene Moieties: Synthesis, Optical, and Electrochemical Properties. J. Appl. Polym. Sci. 2010, 115, 1480-1488. [CrossRef]

38. Alam, S.; Akhtar, M.S.; Abdullah; Kim, E.-B.; Shin, H.-S.; Ameen, S. New energetic indandione based planar donor for stable and efficient organic solar cells. Sol. Energy 2020, 201, 649-657. [CrossRef]

39. Min, J.; Luponosov, Y.N.; Gerl, A.; Polinskaya, M.S.; Peregudova, S.M.; Dmitryakov, P.V.; Bakirov, A.V.; Shcherbina, M.A.; Chvalun, S.N.; Grigorian, S.; et al. Alkyl chain engineering of solution-processable star-shaped molecules for high-performance organic solar cells. Adv. Energy Mater. 2014, 4, 1301234. [CrossRef]

40. Alam, S.; Akhtar, M.S.; Abdullah; Kim, E.-B.; Shin, H.-S.; Ameen, S. Planar D- $\pi$-A configured dimethoxy vinylbenzene based small organic molecule for solution-processed bulk heterojunction organic solar cells. Appl. Sci. 2020, 10, 5743. [CrossRef]

41. Hestand, N.J.; Spano, F.C. Expanded theory of H- and J-Molecular aggregates: The effects of vibronic coupling and intermolecular charge transfer. Chem. Rev. 2018, 118, 7069-7163. [CrossRef] [PubMed]

42. Aytun, T.; Barreda, L.; Carretero, A.R.; Lehrman, J.A.; Stupp, S.I. Improving Solar Cell Efficiency through Hydrogen Bonding: A Method for Tuning Active Layer Morphology. Chem. Mater. 2015, 27, 1201-1209. [CrossRef]

43. Nazim, M.; Ameen, S.; Akhtar, M.S.; Shin, H.-S. Asymmetric, efficient $\pi$-conjugated organic semiconducting chromophore for bulk-heterojunction organic photovoltaics. Dyes Pigments 2018, 149, 141-148. [CrossRef] 
44. Do, T.T.; Pham, H.D.; Manzhos, S.; Bell, J.M.; Sonar, P. Molecular Engineering Strategy for High Efficiency Fullerene-Free Organic Solar Cells Using Conjugated 1,8-Naphthalimide and Fluorenone Building Blocks. ACS Appl. Mater. Interfaces 2017, 9, 16967-16976. [CrossRef] [PubMed]

45. Laure, B.; Christos, L.C.; Nicolas, L.; Georges, H.; Joannis, K.K.; Rony, B.; Patrick, L.; Thomas, H.A. [3,2-b]thienothiophene-altbenzothiadiazole copolymer for photovoltaic applications: Design, synthesis, material characterization and device performances. J. Mater. Chem. 2009, 19, 4946-4951.

46. An, B.-K.; Lee, D.-S.; Lee, J.-S.; Park, Y.-S.; Song, H.-S.; Park, S.Y. Strongly fluorescent organogel system comprising fibrillar self-Assembly of a trifluoromethyl-based cyanostilbene derivative. J. Am. Chem. Soc. 2004, 126, 10232-10233. [CrossRef]

47. Zawodzki, M.; Roland, R.; Sferrazza, M.; Kettner, O.; Friedel, B. Interfacial morphology and effects on device performance of organic bilayer heterojunction solar cells. ACS Appl. Mater. Interfaces 2015, 7, 16161-16168. [CrossRef] [PubMed]

48. Fijahi, L.; Akhtar, M.S.; Abdullah; Kim, E.-B.; Seo, H.-K.; Shin, H.-S.; Ameen, S. Investigation of newly designed asymmetric chromophore in view of power conversion efficiency improvements for organic solar cells. Mater. Lett. 2020, 260, 126865. [CrossRef]

49. He, G.; Wan, X.; Li, Z.; Zhang, Q.; Long, G.; Liu, Y.; Hou, Y.; Zhang, M.; Chen, Y. Impact of fluorinated end groups on the properties of acceptor-donor-acceptor type oligothiophenes for solution-processed photovoltaic cells. J. Mater. Chem. C 2014, 2, 1337-1345. [CrossRef]

50. Lu, Z.; Liu, W.; Li, J.; Fang, T.; Li, W.; Zhang, J.; Feng, F.; Li, W. The Influence of Fluorination on Nano-Scale Phase Separation and Photovoltaic Performance of Small Molecular/PC71BM Blends. Nanomaterials 2016, 6, 80. [CrossRef]

51. Cho, S.N.; Lee, W.H.; Park, J.B.; Kim, J.H.; Hwang, D.H.; Kang, I.N. Synthesis and characterization of fluorine atom substituted new BDT-based polymers for use in organic solar cells. Synth. Met. 2015, 210, 273-281. [CrossRef]

52. Zhang, C.; Song, X.; Liu, K.K.; Zhang, M.; Qu, J.; Yang, C.; Yuan, G.Z.; Mahmood, A.; Liu, F.; He, F.; et al. Electron-deficient and quinoid central unit engineering for unfused ring-based A1-D-A2-D-A1-type acceptor enables high performance nonfullerene polymer solar cells with high Voc and PCE simultaneously. Small 2020, 16, 1907681. 